\title{
Weed dynamics on Amazonian Dark Earth and adjacent soils of Brazil
}

\author{
Julie Major $^{\mathrm{a}, *}$, Antonio DiTommaso ${ }^{\mathrm{a}}$, Johannes Lehmann ${ }^{\mathrm{a}}$, Newton P.S. Falcão ${ }^{\mathrm{b}}$ \\ ${ }^{\mathrm{a}}$ Department of Crop and Soil Sciences, Cornell University, Ithaca, NY 14853, USA \\ ${ }^{\mathrm{b}}$ Coordenação de Pesquisas em Ciências Agronômicas, Instituto Nacional de Pesquisas da Amazônia (INPA), \\ 69060-001 Manaus, Amazonas, Brazil
}

Received 27 May 2004; received in revised form 21 April 2005; accepted 27 April 2005

\begin{abstract}
Field trials were conducted on Amazonian Dark Earth soils in the Manaus region, Amazonas, Brazil to assess the composition and impact of weedy vegetation on maize yield. Soil fertility among the Dark Earth varied considerably with differences largely attributable to past-use history. Consequently, maize yield and weed pressure varied among field locations, reflecting these differences in soil fertility in addition to differences in weed reservoirs such as seedbanks. Maize yield in weeded plots was as much as 63 times greater on Dark Earth $\left(0.55 \mathrm{t} \mathrm{ha}^{-1}\right)$ than on corresponding adjacent soil $\left(0 \mathrm{tha}^{-1}\right)$, and location averages varied from 0 to $3.15 \mathrm{t} \mathrm{ha}^{-1}$ for Dark Earth. The percentage ground cover of weeds in weedy plots was up to 45 times greater on Dark Earth (65-99\%) than on corresponding adjacent soil (2-89\%), and species richness was up to 11 times greater on Dark Earth (4-14 species) than corresponding adjacent soil (1-8 species). The relative proportion of annual and leguminous weeds was 32 and $17 \%$ greater, respectively, on Dark Earth than adjacent soil, and vegetative sprouting of plants was more common on sites that had been used less intensively in the past. In general, a similar weed community was observed on the different Dark Earth sites, including many species typically associated with environments that have been highly disturbed by human activities, such as Cyperus spp., Phyllantus niuri, and Croton lobatus. Seedlings from a greater number of species emerged from forested Dark Earth seedbanks ( 2.1 per flat) than from forested adjacent soil (1.2 per flat). The total number of emerged seedlings was greater for Dark Earth seedbanks (9.1 per flat, $1,365 \mathrm{~m}^{-2}$ ) than adjacent soil $\left(2.2\right.$ per flat, $\left.330 \mathrm{~m}^{-2}\right)$, however the species observed were not likely to be problematic for cropping.
\end{abstract}

(C) 2005 Elsevier B.V. All rights reserved.

Keywords: Derris amazonica; Seedbanks; Soil fertility; Terra preta de Índio; Tropical soil; Zea mays

\footnotetext{
* Corresponding author at: Department of Crop and Soil Sciences, 918 Bradfield Hall, Cornell University, Ithaca, NY 14853, USA. Tel.: +1 607255 1730; fax: +1 607 255-3207.

E-mail address: jm322@cornell.edu (J. Major).
}

\section{Introduction}

Amazonian Dark Earth (DE; locally called Terra Preta de Índio) patches occur in upland (i.e. nonflooded) environments throughout the Amazon 
Basin, and result from soil formation processes that occurred in pre-Columbian times in areas settled by indigenous people. In general, the significantly higher organic matter and phosphorus $(\mathrm{P})$ contents, increased cation exchange capacity and $\mathrm{pH}$, and lower aluminum (Al) levels (Kern and Kämpf, 1989; Lehmann et al., 2003) allow more intensive agricultural uses of DE soils than adjacent soils (AS). Based on the Brazilian soil classification system, these adjacent soils are considered to be primarily nutrient-impoverished, acidic Latossolos (Salgado Vieira, 1988), which correspond to Oxisols and Ultisols in the USDA soil classification system (Soil Survey Staff, 1997). Where markets can be easily accessed, DE soils can be used for permanent, mechanized crop production requiring high external inputs. In more remote areas, swidden subsistence agriculture is commonly practiced on these soils, with a greater range of crops produced than on AS including maize (Zea mays L.), vegetable, and fruit crops. German (2003) reported that farmers consistently rated the performance of a wide variety of crops to be better on DE than AS. This difference in rating was especially striking for maize, with farmers rating its performance at $2.00 \pm 0.00$ on DE soil and $0.29 \pm 0.62$ on AS, on a scale of 0 to 2 . Fallow periods are reduced by more than $50 \%$ on DE compared with AS, and this results in fewer new swidden areas cleared from mature forest on DE than AS (German, 2003).

In 2003, swidden plots planted to maize on both $\mathrm{DE}$ and AS were used to determine the richness and diversity of the weed flora, as well as maize and weed biomass production on these two contrasting soils. Working hypotheses included that weed and maize biomass would be greater on DE, and that a different, more diverse weed community would be found above and belowground on these soils compared with AS. Surveys were carried out on 16 DE farms to obtain additional data on weed diversity. The seedbanks of DE and AS soils under forest were sampled to assess the initial weed pressure when swidden agriculture is initiated. Differences in seedbank size between AS and DE were not expected, because sampling both soil types under a forest environment would mask any effects of indigenous disturbance and management incurred centuries ago.

\section{Materials and methods}

Field trials were conducted during the first half of 2003. Maize plantings were established at four locations near Manaus, Amazonas, Brazil (Fig. 1). Each location consisted of one planting on DE and another on AS, for a total of eight plantings. All planting sites were under secondary forest regrowth and not cropped when first visited in August 2002. Paired plantings at a given location were established approximately $200 \mathrm{~m}$ apart from each other except at $\mathrm{RP}$, where this distance was $5 \mathrm{~km}$. In the absence of soil analysis data, the location of experimental plots was based largely on soil color; as dark as possible and containing pot shards for DE, and as red or yellow as possible for AS. After slash-and-burn, maize was seeded by hand in all fields between 30 January and 24 February, 2003. The open-pollinated maize cultivar "Solimões" BR 5110, obtained from EMBRAPA (Empresa Brasileira de Pesquisa Agropecuária) was used. Weeds present at the time of seeding were removed by hand or with a hoe. Maize rows were spaced $75 \mathrm{~cm}$ apart with $20 \mathrm{~cm}$ separating individual plants within the row, to give a density of 66,500 plants ha $^{-1}$. The size of each planting was approximately 12 by $13 \mathrm{~m}$. A randomized complete block design was applied, with three blocks arranged perpendicular to the gradient judged most important at each site, for example slope, distance from road or forest edge. The three treatments evaluated were: (i) weeds only, where no maize was seeded, (ii) weedy maize, where weeds were allowed to compete with the maize until harvest, and (iii) weeded maize, where weeds were removed from plots monthly with a hoe. At each planting site, nine $1.5 \mathrm{~m}^{2}$ permanent quadrats were established and considered sampling units. Each quadrat spanned two rows of maize with $1.5 \mathrm{~m}$ perpendicular to the rows and $1 \mathrm{~m}$ along the rows, and included 10 maize plants at seeding. The treatments were applied to an area of approximately $2.25 \mathrm{~m} \times$ $1.6 \mathrm{~m}$, with the permanent quadrat in the center of this area, and an unweeded row of maize served as a buffer between all treated areas.

After seeding, each site was visited monthly for 4 months to collect crop and weed data. At each sampling, all weed individuals in the $1.5 \mathrm{~m}^{2}$ permanent quadrats were identified and counted, and the general physiological stage and percentage ground 


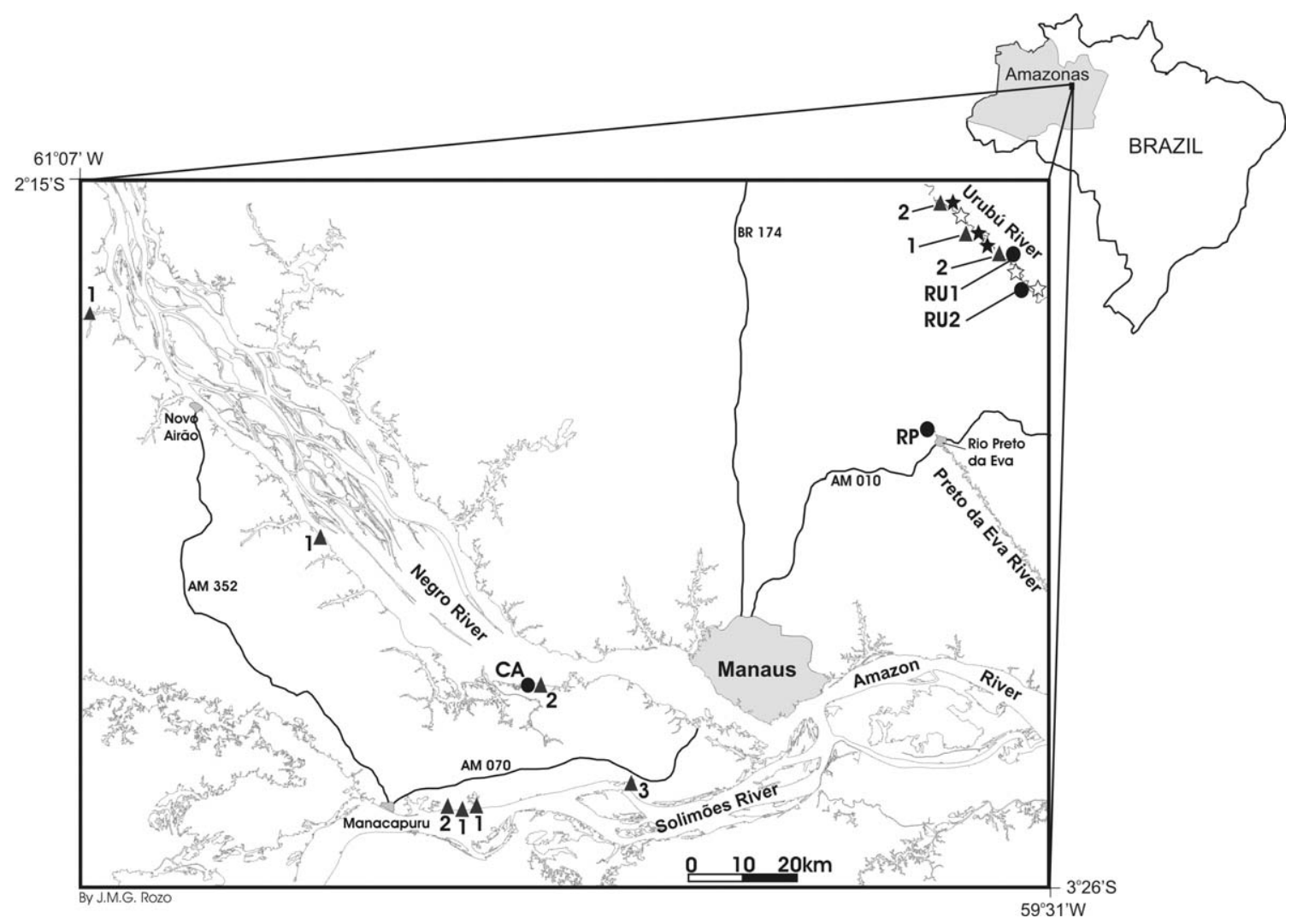

Fig. 1. Location of experimental sites near Manaus, Amazonas, Brazil. Maize trails were conducted at locations CA, RP, RU1 and RU2, and weeds surveys on plots at the locations indicated by $(\boldsymbol{A})$. Numbers indicate the number of plots surveyed at each location. Seedbank samples were taken at locations denoted by $(\star, \mathrm{DE})$ and (馆, AS).

cover of each species recorded. Total ground cover of weeds was calculated as the sum of percentages for individual species. The number of live maize plants was determined in each quadrat. At harvest, maize plants were cut at soil level, separated into ears with husk and stalks, and fresh weights were recorded. Weeds were separated into the two dominant species, seedlings were separated from sprouts, and the fresh weight of all groupings recorded. When possible, all plant material was brought back to the laboratory, dried at $60{ }^{\circ} \mathrm{C}$ for at least $24 \mathrm{~h}$, and weighed.

Weeds were identified with the collaboration of INPA (Instituto Nacional de Pesquisas da Amazônia) and according to Ribeiro et al. (1999) and Lorenzi (2000).

Soil sampling to a depth of $20 \mathrm{~cm}$ was carried out using a Dutch auger. Eight samples were collected at seeding from each $12 \mathrm{~m} \times 13 \mathrm{~m}$ site, and combined into one composite sample per site and sampling time. Potassium $(\mathrm{K})$, calcium $(\mathrm{Ca})$, magnesium $(\mathrm{Mg})$ and $\mathrm{P}$ were extracted using the Mehlich 1 solution $(\mathrm{HCl}$ $0.05 \mathrm{~mol} \mathrm{l}^{-1}+\mathrm{H}_{2} \mathrm{SO}_{4} 0.0125 \mathrm{~mol} \mathrm{l}^{-1}$ ), with available $\mathrm{P}$ determined colorimetrically using the ammonium molybdate with ascorbic acid method, $\mathrm{K}$ determined by flame emission photometry, and $\mathrm{Ca}$ and $\mathrm{Mg}$ determined by atomic absorption spectrophotometry. Exchangeable aluminum was extracted with $1 \mathrm{~mol}^{-1}$ $\mathrm{KCl}$ and the filtrate titrated with $0.025 \mathrm{~mol} \mathrm{l}^{-1} \mathrm{NaOH}$. Total carbon and nitrogen were determined by dry combustion with an automatic Leco CN-2000 CN analyzer (Leco Corporation, St. Joseph, MI, USA). Particle size analysis was carried out using the hydrometer method (Bouyoucos, 1927).

Transects were established on 16 cropped plots on ten farms (Fig. 1), and weeds identified in ten $1.5 \mathrm{~m}^{2}$ quadrats, separated by $1 \mathrm{~m}$ along the transect. Thus, a 
total of $15 \mathrm{~m}^{2}$ were sampled on each of the 16 plots. The plots surveyed were planted to a number of crops, which were at different stages of growth at the time of sampling. A variety of crop management and weed control strategies were used on the different plots. The last weeding prior to the survey ranged from 2 weeks to 2 months. The quadrats sampled for the four DE sites in the maize field experiment, with a total of $13.5 \mathrm{~m}^{2}$ surveyed per site, were also included in the survey.

For the seedbank study, soil samples were collected on 16-17 April 2003 along the Urubú River, Amazonas, Brazil (Fig. 1), in the latter part of the rainy season that typically lasts from December to May. All sampling locations were under old forest, and based on knowledge from local inhabitants had not been disturbed. For AS sites, this likely meant that these areas were under "virgin" forest, whereas the DE sites had probably not been cropped since abandonment by Indigenous people when their populations were decimated between 1600 and 1700 A.D. Six locations were sampled: Z, A, and S on DE and $\mathrm{D}, \mathrm{I}$, and $\mathrm{L}$ on AS. At each site, a transect was established approximately $10 \mathrm{~m}$ into the forest and parallel to the edge of fallow or cropped fields. At one meter intervals for a distance of $10 \mathrm{~m}$, sampling was carried out along a $1 \mathrm{~m}$ line perpendicular to the transect. Using a Dutch auger, four equidistant soil cores were taken along this line on either side of the transect, to a depth of $15 \mathrm{~cm}$. Coarse debris and loose surface roots were removed before sampling. The four samples collected for each of the $10 \mathrm{~m}$ locations were combined to yield 10 composite samples per sampling location. The sampling area of $667 \mathrm{~cm}^{2}$ is within the range used in other similar studies, such as Uhl and Clark, 1983 and Benoit et al., 1989.

Samples were air-dried for one week in the dark before processing. After breaking large soil aggregates by hand, 11 sub-samples of soil were placed in plastic germination flats. Sixty flats, 10 for each of the six locations, were placed in a screenhouse receiving natural light with flats arranged in a completely randomized design. The photoperiod during the trial was approximately $12 \mathrm{~h}$, and previous data show that temperatures inside the screenhouse during the study period averaged $31{ }^{\circ} \mathrm{C}$ but could have reached a daily maximum of $41{ }^{\circ} \mathrm{C}$. Twenty control flats containing 11 of DE soil of unknown origin autoclaved at $101 \mathrm{kPa}$ and $120^{\circ} \mathrm{C}$ for $30 \mathrm{~min}$ were also included. Species emerging in the control flats were considered to have been carried into the screenhouse, which was not fully screened from the outside, and were excluded from the analysis. Flats were watered as required, but not fertilized. Emergence was assessed twice weekly for approximately 59 days. Emerged seedlings were removed and transplanted into separate pots until they could be identified. Due to high temperatures in the screenhouse, shallow soil depths in the flats and logistical limitations, excessive soil drying occurred on several occasions, resulting in $37 \%$ of observed seedlings dying before they could be identified. Hereafter, these seedlings are categorized as being "unaccounted".

Analyses of variance were performed using the GLM procedure in SAS (SAS Institute, 2001), with all terms treated as fixed variables except location in the seedbank study, which was treated as a random variable nested within soil type. After examining residual plots, weed percentage ground cover data were arcsine-square root transformed, counts of weed individuals as well as seedbank emergence counts were square root transformed, and biomass data were $\log$ transformed to stabilize variance. In analyses, ramets of species reproducing by rhizomes or root sprouts were considered to be separate individuals. Sorensen's coefficient of similarity (S) was used to compare weed communities at different sites, according to the equation

$S=\frac{2 c}{s_{1}+s_{2}}$

where $c$ is the number of species common to both communities, $s_{1}$ is the number of species in the first community and $s_{2}$ is the number of species in the second community. Pearson Moment Correlation coefficients were calculated for the various weed and maize parameters.

\section{Results and discussion}

\subsection{Soil fertility}

DE soils at CA and RU1 were more fertile than their corresponding AS areas, as evidenced by higher $\mathrm{pH}, \mathrm{P}$ content and base saturation, and lower $\mathrm{Al}$ 
Table 1

Key soil properties of samples taken in February 2003 after slash-and-burn of secondary growth on four Amazonian Dark Earth (DE) and four adjacent soils (AS) in the central Brazilian Amazon

\begin{tabular}{llcllccccc}
\hline Parameter & Unit & CA-DE & CA-AS & RP-DE & RP-AS & RU1-DE & RU1-AS & RU2-DE & RU2-AS \\
\hline $\mathrm{pH}$ & $\left(\mathrm{CaCl}_{2}\right)$ & 5.02 & 4.07 & 4.71 & 5.03 & 4.62 & 4.48 & 4.51 & 4.47 \\
$\mathrm{P}$ & $\left(\mathrm{mg} \mathrm{kg}^{-1}\right)$ & 200.1 & 5.1 & 44.8 & 2.8 & 15.0 & 3.4 & 7.5 & 4.0 \\
BS $^{\mathrm{a}}$ & $(\%)$ & 65 & 2 & 12 & 24 & 20 & 2 & 2 & 4 \\
ALS $^{\mathrm{b}}$ & $(\%)$ & 0 & 19 & 14 & 12 & 10 & 19 & 17 & 17 \\
\hline
\end{tabular}

a Base saturation.

b Aluminum saturation.

saturation (Table 1). DE soils at RP and RU2, however, exhibited high Al saturation, low $\mathrm{P}$ content in the case of RU2-DE, and lower base saturation than the corresponding AS areas (Table 1). Past management may have negatively affected fertility levels, resulting in a fertility gradient among DE sites.

\subsection{History of study sites}

Important differences in past-use history characterized the field sites used in this study. For this reason, the field sites were divided into two groups, based on the intensity of past-use history. The "intensive-use" sites include locations CA and RP (Fig. 1, Table 2), which are closer to markets in Manaus and Rio Preto da Eva, in the case of RP, and where most DE land is under permanent crop production. At the CA-DE site, land use prior to fallowing was intensive as remnants of a road and a suspected dwelling were noticed on the experimental plot. Similarly, the RP-DE site was used as a cattle pasture from 1988 to 1996. The intensive past use of these sites contrasts with the "light-use" sites and may have influenced weed-crop dynamics.

The "light-use" sites include RU1 and RU2. These sites are further away from the city of Manaus and, therefore, market access is substantially reduced. Although some horticultural crops are produced for market on a small scale, subsistence agriculture is the dominant practice on these sites. Experimental plots selected at these "light-use" sites reportedly had been under fallow for shorter periods than plots in the more intensive-use sites, although cropping had not been as intensive.

\subsection{Maize performance}

The effects of soil type, DE or AS, site, and their interaction on maize yield were all highly significant
$(P<0.0001)$. While yields were low, maize dry ear biomass was greatest on the more fertile DE sites CA and RU1 (1.4 and $3.2 \mathrm{tha}^{-1}$, respectively). Lower than expected yields at the CA-DE versus the RU1-DE site were likely due to soil compaction from a road crossing the CA-DE site in the past. At the CA-AS and RU2-AS sites no ears were produced. The CA-DE site, although subjected to high disturbance and soil compaction in the past, did not experience large soil fertility declines as might be expected.

Weeding did not have a significant effect $(P>0.05)$ on overall maize performance. In general, maize did not respond to weed removal, however at the CA-DE site both ear and stalk biomass were, on average, more than double in weeded plots $\left(1.9 \mathrm{t} \mathrm{ha}^{-1}\right.$ ear) versus non-weeded plots $\left(0.9 \mathrm{t} \mathrm{ha}^{-1}\right.$ 1 ear). In contrast to other sites, weed pressure at the CA-DE site occurred early but decreased rapidly following the removal of weeds 1 month after seeding when maize was at the six-leaf stage. Yield losses in maize ranging from 2 to $28 \%$ have been reported in temperate regions, when weed removal was delayed until four weeks after seeding (Wilson and Westra, 1991; Hall et al., 1992; Hellwig et al., 2002). Higher soil fertility may increase the period during which maize crops can tolerate weeds such as in Nebraska, where the initiation of the critical period for weed control in a maize field was delayed until the six-leaf stage with a nitrogen (N) application of $120 \mathrm{~kg} \mathrm{ha}^{-1}$, and resulted in an acceptable yield loss of 5\% (Evans et al., 2003). When no fertilizer was added, the critical period for weed control occurred at the two-leaf stage of maize. Similarly, maize was better able to tolerate weed pressure with a $220-250 \mathrm{~kg} \mathrm{~N} \mathrm{ha}^{-1}$ application as opposed to a $100-130 \mathrm{~kg} \mathrm{~N} \mathrm{ha}^{-1}$ application in field trials in southwestern Ontario, Canada (Tollenaar et al., 1994). 
Table 2

Field site description, method of land preparation, and intensity of burn for four Amazonian Dark Earth (DE) and four adjacent soil (AS) sites in the central Brazilian Amazon

\begin{tabular}{|c|c|c|c|c|}
\hline Location name & Location code & Standing vegetation $^{\mathrm{a}}$ & Method of land preparation & Intensity of burn $^{\mathrm{b}}$ \\
\hline \multirow[t]{2}{*}{ Costa do Açutuba } & CA-DE & $\begin{array}{l}\text { More than } 10 \text { year old regrowth, dominated } \\
\text { by Senna sp. trees } 15 \mathrm{~cm} \text { diameter at base. } \\
\text { Suspected location of a dwelling. }\end{array}$ & Slashed wk of Jan. 21, 2003 & Not burned \\
\hline & CA-AS & Virgin forest, trees $25 \mathrm{~m}$ high & $\begin{array}{l}\text { Slashed in Feb. 2002, burned in July 2002, } \\
\text { hoed before planting }\end{array}$ & Intense \\
\hline \multirow[t]{2}{*}{ Rio Preto da Eva } & RP-DE & $\begin{array}{l}\text { 7-Year old regrowth after pasture abandonment, } \\
\text { trees sparsely distributed, } 5 \mathrm{~m} \text { high }\end{array}$ & $\begin{array}{l}\text { Slashed wk of Jan. 28, 2003, } \\
\text { burned wk of Feb. 10, } 2003\end{array}$ & Light \\
\hline & RP-AS & $\begin{array}{l}\text { Virgin forest cleared in } 1995 \text { and planted to rice, } \\
\text { then manioc and fruit trees planted in } 1996 \text {, } \\
\text { site somewhat abandoned at time } \\
\text { experiment established }\end{array}$ & $\begin{array}{l}\text { Slashed, and burned and cleaned with a hoe } \\
\text { wk of Jan. 10, } 2003\end{array}$ & Light \\
\hline \multirow[t]{2}{*}{ Rio Urubu 1} & RU1-DE & $\begin{array}{l}\text { 6-Year old regrowth dominated } \\
\text { by Ocotea sp., } 10 \mathrm{~m} \text { high }\end{array}$ & $\begin{array}{l}\text { Understory slashed wk of Jan. } 28,2003 \text {, } \\
\text { trees cut Feb. } 4 \text {, burned wk of Feb. } 5 \text {, } \\
\text { branches removed by hand before lightly } \\
\text { re-burning the leaf litter and planting }\end{array}$ & Moderate \\
\hline & RU1-AS & $\begin{array}{l}\text { 16-Year old regrowth dominated } \\
\text { by Vismia sp., } 10 \mathrm{~m} \text { high }\end{array}$ & $\begin{array}{l}\text { Cleared Sept. 2002, burned wk of Feb. } 5 \text {, } \\
\text { branches removed by hand before lightly } \\
\text { re-burning the leaf litter and planting }\end{array}$ & Moderate \\
\hline \multirow[t]{2}{*}{ Rio Urubu 2} & RU2-DE & $\begin{array}{l}\text { 3-Year old regrowth dominated } \\
\text { by Vismia sp., } 10 \mathrm{~m} \text { high, } \\
\text { tree diameter between } 3 \text { and } 10 \mathrm{~cm} \text { at base }\end{array}$ & Cleared and burned Nov. 2002 & Moderate \\
\hline & RU2-AS & $\begin{array}{l}\text { 8-Year old regrowth slashed in } 2001, \\
\text { not previously planted to crops }\end{array}$ & $\begin{array}{l}\text { Re-cut Nov. 2002, burned } 7 \text { Feb. 2003, plot } \\
\text { cleaned with a hoe }\end{array}$ & Light \\
\hline
\end{tabular}

\footnotetext{
${ }^{\text {a }}$ As observed and reported by local inhabitants.
}

${ }^{\mathrm{b}}$ Light: tree trunks and most branches left unburned, moderate: most tree branches burned, intense: most plant material burned. 


\subsection{Weed population}

Weed populations measured at the different sites varied widely. For example, a weed cover of $100 \%$ was obtained on plots at the CA-DE site, while some nonweeded plots at the CA-AS site had a weed cover of $0 \%$. Consequently, there was a significant interaction $(P<0.05)$ between site and soil type for the number of weeds, percentage ground cover and biomass. The percentage ground cover of weeds was strongly correlated to their dry biomass at harvest (Pearson's correlation coefficient $=0.8, P<0.0001$ ), whereas the total number of individual weed plants in the $1.5 \mathrm{~m}^{2}$ quadrats was poorly correlated with their cover and biomass. Positive weed responses on DE soils were most apparent on the more fertile DE sites CA ( $98.5 \%$ cover) and RU1 (77.3\% cover), in comparison to AS at these same sites (2.2 and $26.7 \%$, respectively). Weed cover on AS was greatest at the RP site where Solanum subinerme Jacq. was found, which reproduces vigorously by root sprouts. Biomass was generally greater in the plots with only weeds compared to those with weedy maize. As expected, the weeded maize plots had significantly fewer weeds, lower weed ground cover and biomass at harvest than other treatment plots. At harvest, after 4 monthly hand weedings, weed cover was greater on weeded DE plots at RP (28\%) and CA (19\%) sites than on similar plots at the other two sites (on average 6.5\%) $(P<0.05)$. The seedbank at the CA site was probably very large since within 1 month of the start of the trial, annual weeds and especially Euphorbia heterophylla L. were the dominant group and comprised nearly $80 \%$ of the ground cover (Fig. 2). At the RP-DE site, however, the dominant species on weeded plots at harvest were members of the Cyperaceae such as Cyperus cf. aggregatus Endl., C. cf. diffusus Vahl, and Rhynchospora nervosa (Vahl) Boeck. subsp. ciliata $\mathrm{T}$. Koyama, which reproduce primarily vegetatively.

On more fertile DE soils at sites CA and RU1, the better performance of maize reduced weed cover in the weedy maize plots on average by 32 and $58 \%$ at CA and RU1, respectively, compared with the plots where only weeds grew, whereas this was not the case at the less fertile DE sites. Early weed emergence at the CA-DE site likely explains why differences in weed coverage between the weed-only and weedy maize plots were not as drastic as for the RU1-DE site, where weed emergence was more gradual. Similar findings were obtained by Jornsgard et al. (1996) in a cereal field experiment in Denmark. At lower $\mathrm{N}$ applications of $30-54 \mathrm{~kg} \mathrm{~N} \mathrm{ha}^{-1}$, crop growth and

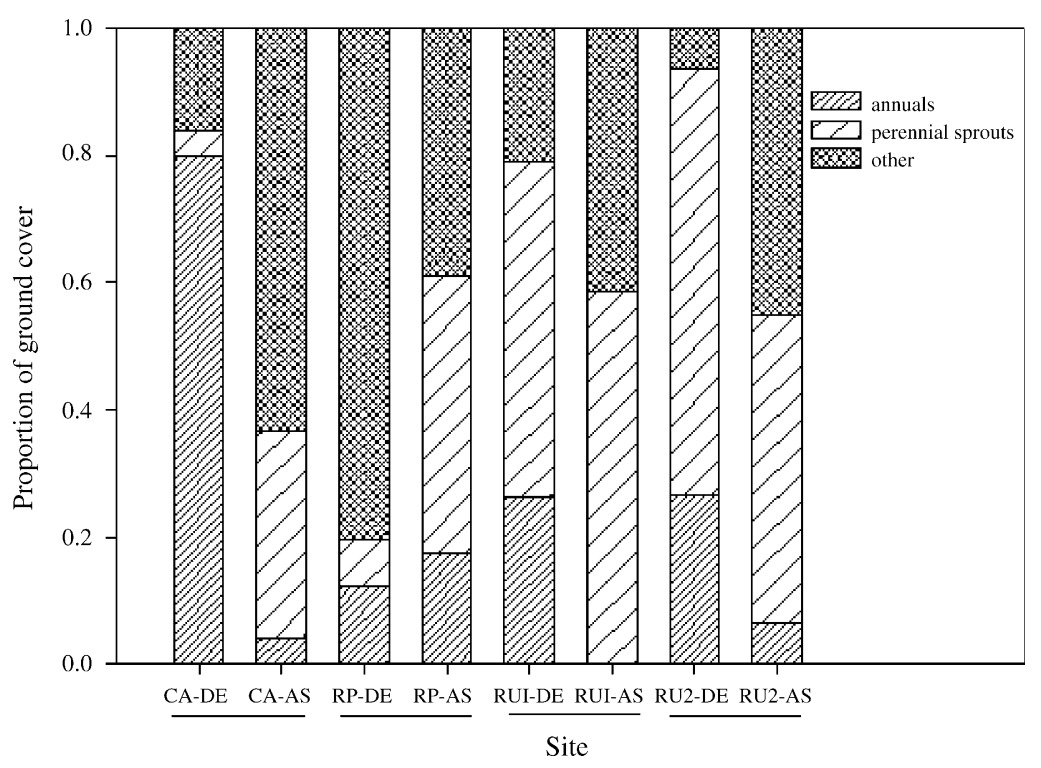

Fig. 2. Proportion of ground cover comprised of annual weeds and perennial sprouts at four Amazonian Dark Earth (DE) and four adjacent soil (AS) sites in the central Brazilian Amazon. The "other" category includes sedges, perennials reproducing by seed, species that can behave as annuals or perennials, and species that could not be identified. 
development were reduced and weed growth favored because a greater proportion of light reached the weeds. At higher $\mathrm{N}$ application rates of 90 $162 \mathrm{~kg} \mathrm{~N}^{-1}$, crop growth was improved and plants were able to overtop and shade out the weeds.

The greater weed pressure observed early in the growing season on the CA-DE site was likely due to the high disturbance history of the site and to it not being burned (Table 2). Fire has been demonstrated to reduce seedbanks in proportion to its intensity (Monaco, 1998).

\subsection{Weed species richness and dominance}

A total of 77 plant species were identified at the eight experimental sites. Mean species richness for individual permanent quadrats was greater on DE than AS soils, 8.0 and 4.2 respectively, except at the RU2 site, which had similarly low chemical fertility on both soil types. The greatest number of species was found at the CA-DE site, while the lowest number of species was at the CA-AS site, 29 and 5 respectively.

Species richness has often been observed to follow a unimodal pattern along a productivity gradient, with the highest diversity occurring at moderate productivity levels and lowest diversity found at range extremes (Grime, 1979; Stevens and Carson, 1999). Other factors may also be critical, with disturbance playing an especially important role in facilitating species colonization (Grace, 1999 and references therein). In DE crop production systems, fertility and disturbance are often closely linked. In general, DE soils are located closer to disturbed or open areas such as rivers and dwellings, where plant dispersal and migration are facilitated. In addition, DE soils are subjected to more frequent disturbance, with shorter fallow periods (German, 2003). Weed dispersal and colonization are also assisted by the use of manure and weed seed-contaminated soil amendments, which are most often applied to DE soils and not AS in smallholder agricultural production systems.

Weed communities on DE sites had a more similar species composition $(P=0.069)$ than on AS sites. Many weed species present on sites CA and RP characterized as having an "intensive-use" history were also observed in urban areas of Manaus including roadsides and abandoned lots. Examples of these "cosmopolitan species" include Euphorbia hirta L.,
E. heterophylla, Phyllanthus niuri L., Cyperus cf. aggregatus, C. cf. diffusus, and Microtea debilis Sw., all of which are native to the Americas, and Acalypha arvensis Poepp. and Endl., whose origin is unknown.

On some sites, a single species represented more than $60 \%$ of the weed coverage at harvest. Examples include Spermacoce latifolia Aubl. at the RU1-DE site and P. niuri at the CA-DE site. However, no single weed species was dominant across all field sites. Sixty-two percent or 48 out of 77 weed species were found on only one site, including E. heterophylla L., Sida rhombifolia L., and S. subinerme Jacq. which were each dominant on the site they colonized. Interestingly, S. rhombifolia has been reported to be an indicator species of high soil fertility in Costa Rica (de la Cruz, 1994) and we found this species only on the CA-DE site, the most fertile of the sites. Dominance of grasses and sedges was reported on intensively managed soils of Nigeria and Uganda where fertility declines had occurred (Ugen and Wortman, 2001; Akobundu and Ekeleme, 2002). In this study, sedges and grasses were each dominant with $>40 \%$ of total weed cover on four sites: RP-DE, which was previously used for pasture, and three AS sites: RPAS, RU1-AS, and RU2-AS. The leguminous woody vine, Derris amazonica Killip, was present on all sites except CA, although sometimes at very low densities.

\subsection{Leguminous weeds}

Although differences varied significantly between sites, the number of leguminous individuals and their percentage ground cover was greater on DE than AS (average 21 and 4\%, respectively, $P<0.0001$ ). Legumes occupied the greatest proportion of ground cover on "light-use" sites RU1 and RU2 where the woody vine $D$. amazonica Killip was dominant. This species relies largely on vegetative sprouting for propagation and, for this reason, is expected at higher densities where burns are less frequent and intense (de Rouw, 1993) and where weeding is less intensive (Kellman, 1980).

High availability of $\mathrm{P}, \mathrm{Ca}$, and micronutrients as well as low $\mathrm{N}$ availability stimulate the biological fixation of atmospheric $\mathrm{N}_{2}$, which gives legumes a competitive advantage on DE (Lehmann et al., 2003) explaining the greater proportion of legume weeds observed on DE than AS. In fact, $\mathrm{N}$ availability has 
been found to be reduced in DE soils because of high $\mathrm{C}: \mathrm{N}$ ratios.

\subsection{Weed reproductive strategy}

Annual species constituted a greater proportion of weeds and vegetative cover on DE soils than AS $(P<0.05)$, although differences varied significantly between sites (Fig. 2). This finding is consistent with work by Tilman (1987) and Dieleman et al. (2000) in temperate regions showing that annuals are most abundant on more fertile soils. The greatest differences in the proportion of ground cover comprised by annuals occurred at locations CA and RU1, where fertility differences between DE and AS were greatest.

Weeds entered the reproductive phase earlier on DE than AS sites. During the experiment, an average of $50 \%$ of the species occurring on DE sites and $31 \%$ of those occurring on AS sites flowered. These differences could be due to the contrasting phenologies of the species observed on each soil type rather than effects of the soil per se. More annual species were found on DE soils than AS, and these are expected to flower and set fruit earlier than most perennial species.
Interestingly, weed species found on both soil types did not differ in their timing of flowering and fruit set.

The proportion of biomass from woody sprouting vegetation was greater at sites having "light-use" histories, and did not vary significantly with soil type or weed treatment. Sprouting, as a regenerative strategy, is facilitated on sites with low weeding intensity, less frequent or lighter burns (Kellman, 1980; Uhl et al., 1982; de Rouw, 1993). The substantially lower woody sprout biomass at the RP-DE site was likely due to the site being used for pasture for 8 years, while at CA-DE the presence of a dwelling in the past could explain the lower sprout biomass obtained (Fig. 2).

\subsection{Weed survey}

Ninety-eight species were identified in the weed survey of $20 \mathrm{DE}$ plots including those surveyed for the maize trial. A wider diversity of weeds was recorded, compared to that found in the controlled maize experiment, with 44 of the species found on only one surveyed plot. The most frequent species were $A$. arvensis Poepp. and Endl. (frequency $(f)=0.65), P$.

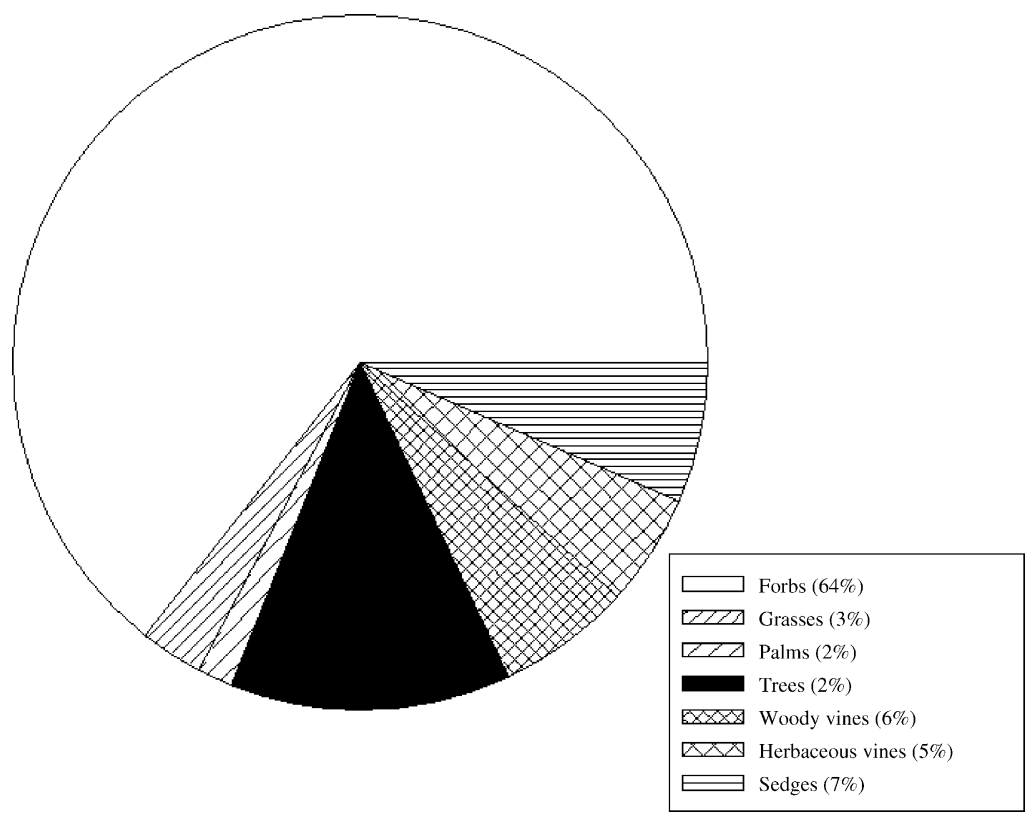

Fig. 3. Frequency ratings by life form for weeds surveyed on 16 cropped Amazonian Dark Earth (DE) plots in the central Brazilian Amazon. Shrubs and epiphytes are not included since each had a frequency of $0.6 \%$. 
niuri L. $(f=0.60)$, and Mollugo verticillata $\mathrm{L}$. $(f=0.55)$. All three may be considered "cosmopolitan" species, as they were frequently observed growing in highly disturbed, urban areas. Thirteen species were in the Euphorbiaceae family and accounted for $24 \%$ of frequency recordings. Forbs were the most frequently recorded life form, followed by trees (Fig. 3). Overall, $57 \%$ of species surveyed were perennials, $24 \%$ were annuals and $19 \%$ not known.

\subsection{Seedbanks}

Seedlings from a total of 15 species were recorded: one member each of the Cyperaceae and Leguminoseae, three members of Cecropia, one member each of Vismia and Fittonia, Solanum appressum K.E. Roe, Trema micrantha Blume, and six species groups that could not be identified by name. In general, more seedlings emerged in DE soils than AS (9.1 versus 2.2 per flat, respectively, $P<0.05)$, but there were significant differences $(P<0.05)$ between sampling locations. Similarly, seedlings of more species emerged from DE soils than AS (2.1 versus 1.2, respectively, $P<0.1$ ), with no significant effect of sampling location. These values convert to 1,365 and 330 seedlings $\mathrm{m}^{-2}$ for DE soils and AS, respectively.
The mean seedling density for AS corresponds to densities and associated seedbank sizes of 344-862 seedlings $\mathrm{m}^{-2}$ reported by Guevara and GomezPompa (1972) for tropical forest soils. The seedling density for DE soils and its associated seedbank size is within the 2,300 seedlings $\mathrm{m}^{-2}$ range reported by Garcia (1995) for agricultural soils in the tropics, even though the sample area was not under agricultural production. The rate of seedling emergence was greatest between days 21 and 31 and was generally consistent across locations. Emergence rates decreased gradually thereafter (Fig. 4).

The observed differences between DE and AS are likely due to different levels of disturbance associated with the areas adjacent to sampling locations. In a slash-and-burn agricultural system where no tillage is practiced, increased disturbance leads to increased weed biomass and seedbanks when compared with fallowing (Akobundu et al., 1999; Ekeleme et al., 2004). Disturbance is increased on DE because shorter fallows are used (German, 2003), and these soils are often cropped more intensively, at least when markets are accessible. Furthermore, while swiddens on AS are sometimes cleared far from permanent living areas or even on land not directly adjacent to them, dwellings are usually located close to swidden plots on DE, and therefore disturbance is increased. In fact, DE location

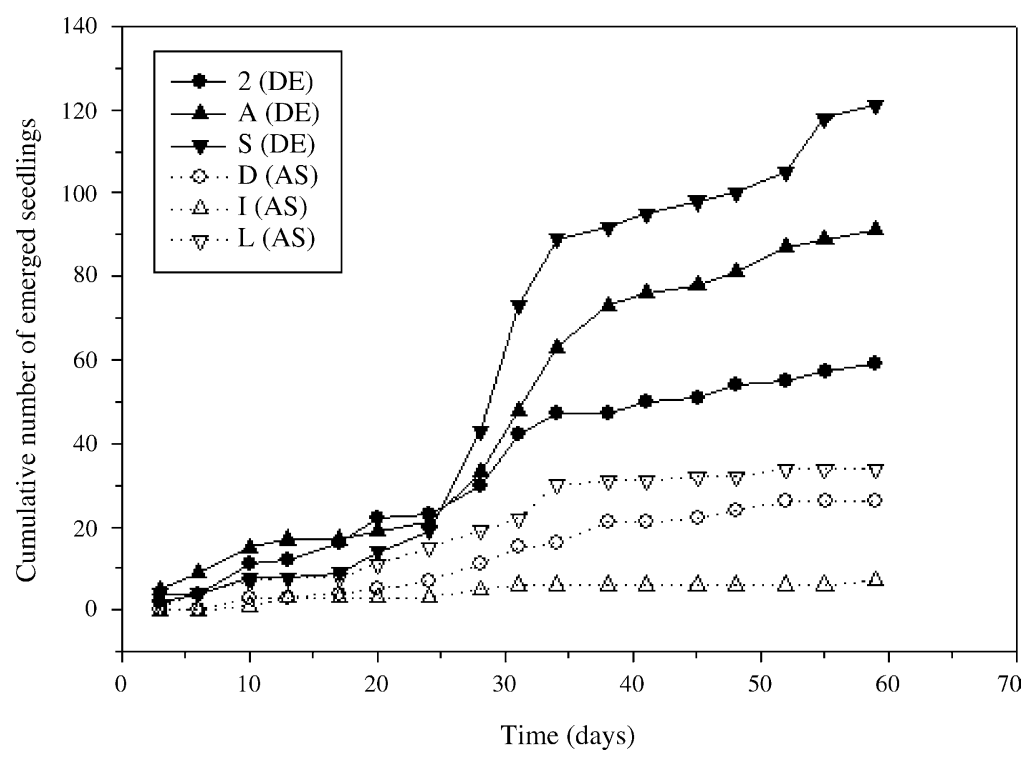

Fig. 4. Cumulative number of emerged seedlings over an 8-week period in a screenhouse for $667 \mathrm{~cm}^{2}$ soil samples from undisturbed soils collected at three Amazonian Dark Earth (DE) and three adjacent soil (AS) locations in the central Brazilian Amazon. 
$\mathrm{S}$ was located closest to the river $(60 \mathrm{~m})$, and had the highest seedling emergence during this trial. A larger population of weeds and early successional species is likely responsible for increased seedbanks in DE sampling areas, via wind and animal dispersal, for example.

A Cecropia sp. was the only species found in all locations. Seeds of this early successional tree genus can remain viable in soil for more than 5 years (Holthuijzen and Boerboom, 1982), but manual weeding likely easily controls plants since seedlings cut at soil level would probably not recover. The species identified in this study were not representative of weeds typically occurring in the surveyed DE plots.

\section{Acknowledgements}

This work was made possible by the generous collaboration of Dr. Charles R. Clement, at INPA in Manaus, AM, Brazil. We are indebted to the farmers who allowed us to work on their land, especially Luis Ferreira da Silva and Francisca Leite and their families. We thank João de Deus L. de Castro from EMBRAPA-Amazônia Ocidental for logistical help, Dr. Takashi Muraoka at CENA in Piracicaba, SP, Brazil for soil analyses, and Dr. Steven J. Schwager and Françoise Vermeylen at Cornell University for their guidance with statistical analyses. Funding for this work was provided by the Saltonstall Fellowship of the Department of Crop and Soil Sciences at Cornell University, the Fonds Québécois de Recherche sur la Nature et les Technologies and travel grants from the Cornell International Institute for Food, Agriculture and Development and the Einaudi Center for International Studies, at Cornell University. Dr. Sam Fujisaka, Dr. Charles L. Mohler, Dr. Daniel C. Brainard and two anonymous reviewers provided valuable comments for the improvement of earlier versions of the manuscript.

\section{References}

Akobundu, I.O., Ekeleme, F., 2002. Weed seedbank characteristics of arable fields under different fallow management systems in the humid tropical zone of southeastern Nigeria. Agroforest. Syst. 54, 161-170.
Akobundu, I.O., Ekeleme, F., Chikoye, D., 1999. Influence of fallow management systems and frequency of cropping on weed growth and crop yield. Weed Res. 39, 241-256.

Benoit, D.L., Kenkel, N.C., Cavers, P.B., 1989. Factors influencing the precision of soil seed bank estimates. Can. J. Plant Sci. 67, 2833-2840.

Bouyoucos, G.J., 1927. The hydrometer as a new and rapid method for determining the colloidal content of soil. Soil Sci. 23, 319331.

de la Cruz, R., 1994. The usefulness of weed diversity in slash/ mulch bean production: difficulties in herbicide use. In: Thurston, H.D., Smith, M., Abawi, G., Kearl, S. (Eds.), Tapado slash/mulch: How Farmers Use It and What Researchers Know About It. Cornell International Institute for Food, Agriculture and Development (CIIFAD), Ithaca, NY, pp. 233-237.

de Rouw, A., 1993. Regeneration by sprouting in slash and burn rice cultivation, Tai rain forest Cote d'Ivoire. J. Trop. Ecol. 9, 387408.

Dieleman, J.A., Mortensen, D.A., Buhler, D.D., Ferguson, R.B., 2000. Identifying associations among site properties and weed species abundance II. Hypothesis generation. Weed Sci. 48, 576-587.

Ekeleme, F., Chikoye, D., Akobundu, I.O., 2004. Impact of natural, planted (Pueraria phaseoloides, Leucaena leucocephala) fallow and landuse intensity on weed seedling emergence pattern and density in cassava intercropped with maize. Agric. Ecosyst. Environ. 103, 581-593.

Evans, S.P., Knezevic, S.Z., Lindquist, J.L., Shapiro, C.A., 2003. Influence of nitrogen and duration of weed interference on corn growth and development. Weed Sci. 51, 546-556.

Garcia, M.A., 1995. Relationship between weed community and soil seed bank in a tropical agroecosystem. Agric. Ecosyst. Environ. 55, 139-146.

German, L.A., 2003. Historical contingencies in the coevolution of environment and livelyhood: contributions to the debate on Amazonian Black Earth. Geoderma 111, 307-331.

Grace, J.B., 1999. The factors controlling species density in herbaceous plant communities: an assessment. Perspect. Plant Ecol. 2, $1-28$.

Grime, J.P., 1979. Plant strategies and vegetation processes. John Wiley and Sons, London, UK.

Guevara, S., Gomez-Pompa, A., 1972. Seeds from surface soils in a tropical region of Veracruz. Mexico. J. Arnold Arboretum 53, 312-335.

Hall, M.R., Swanton, C.J., Anderson, G.W., 1992. The critical period of weed control in grain corn (Zea mays). Weed Sci. 40, 441-447.

Hellwig, K.B., Johnson, W.G., Scharf, P.C., 2002. Grass weed interference and nitrogen accumulation in no-tillage corn. Weed Sci. 50, 757-762.

Holthuijzen, A.M.A., Boerboom, J.H.A., 1982. The Cecropia seedbank in the Suriname lowland rain forest. Biotropica 14, 62-68.

Jornsgard, B., Rasmussen, K., Hill, J., Christiansen, J.L., 1996. Influence of nitrogen on competition between cereals and their natural weed populations. Weed Res. 36, 461-470.

Kellman, M., 1980. Geographic patterning in tropical weed communities and early secondary successions. Biotropica 12, 34-39. 
Kern, D.C., Kämpf, N., 1989. Antigos assentamentos indígenas na formação de solos com terra preta arqueológica na região de Oriximiná. Pará. Rev. Bras. Cienc. Solo 13, 219-225.

Lehmann, J., Pereira da Silva, J.J., Steiner, C., Nehls, T., Zech, W., Glaser, B., 2003. Nutrient availability and leaching in an archaeological Anthrosol and a Ferralsol of the Central Amazon basin: fertilizer, manure and charcoal amendments. Plant Soil 249, 343-357.

Lorenzi, H., 2000. Plantas Daninhas do Brasil: Terrestres, Aquáticas, Parasitas e Tóxicas, 3rd ed. Instituto Plantarum, Nova Odessa, SP, Brazil.

Monaco, L.M., 1998. O Efeito do Fogo Sobre a Regeneração de Especies Pioneiras na Amazônia Central. Masters thesis, INPA Universidade Federal do Amazonas, Manaus, AM, Brazil.

Ribeiro, J.E.L.S., Hopkins, M.J.G., Vicentini, A., Sothers, C.A., Costa, M.A.S., Brito, J.M., Martins, L.H.P., Lohmann, L.G., Assunção, P.A.C.L., Pereira, E.C., Silva, C.F., Mesquita, M.R., Procópio, L.C., 1999. Flora da Reserva Ducke: Guia de Identificação das Plantas Vasculares de uma Floresta de Terra-Firme na Amazônia Central. INPA-DFID, Manaus, AM, Brazil.

Salgado Vieira, L., 1988. Manual da Ciencia do Solo, com Enfase aos Solos Tropicais, 2nd ed. Editora Agronomica Ceres, São Paulo.
SAS Institute., 2001. SAS version 8e for Windows, Cary, NC.

7th ed. Pocahontas Press, Blackburg, VI.

Stevens, M.H.H., Carson, W.P., 1999. The significance of assemblage-level thinning for species richness. J. Ecol. 87, 490502.

Tilman, D., 1987. Secondary succession and the pattern of plant dominance along experimental nitrogen gradients. Ecol. Monogr. 57, 189-214.

Tollenaar, M., Nissanka, S.P., Aguilera, A., Weise, S.F., Swanton, C.J., 1994. Effect of weed interference and soil nitrogen on four maize hybrids. Agron. J. 86, 596-601.

Ugen, M.A., Wortman, C.S., 2001. Weed flora and soil properties in subhumid tropical Uganda. Weed Technol. 15, 535543.

Uhl, C., Clark, H., Clark, K., Maquirino, P., 1982. Successional patterns associated with slash-and-burn agriculture in the upper Rio Negro of the Amazon basin. Biotropica 14, 249254.

Uhl, C., Clark, K., 1983. Seed ecology of selected Amazon basin successional species. Bot. Gaz. 144, 419-425.

Wilson, R.G., Westra, P., 1991. Wild porso millet (Panicum miliaceum) interference in corn (Zea mays). Weed Sci. 39, $217-220$. 